DOI: 10.15276/hait.04.2020.3

UDC 004.9 + 616-079.4

\title{
FORMING THE STACK OF TEXTURE FEATURES FOR LIVER ULTRASOUND IMAGES CLASSIFICATION
}

\author{
Ievgen A. Nastenko ${ }^{1)}$ \\ ORCID: https://orcid.org/0000-0002-1076-9337, nastenko.e@ gmail.com \\ Volodymyr A. Pavlov ${ }^{1)}$ \\ ORCID: https://orcid.org/0000-0002-3293-5308, pavlov.vladimir264@gmail.com \\ Maksym O. Honcharuk ${ }^{1)}$ \\ ORCID: https://orcid.org/0000-0003-1537-4198, maksymhoncharuk42@ gmail.com \\ Dmitro Y. Hrishko ${ }^{1)}$ \\ ORCID: https://orcid.org/0000-0003-0731-0098, dimagrshk@gmail.com
} 1) National Technical University of Ukraine "Igor Sikorsky Kyiv Polytechnic Institute”, 5a,Mikhail Braichevsky street, Kyiv, Ukraine

\begin{abstract}
This article discusses the use of texture analysis methods to obtain informative features that describe the texture of liver ultrasound images. In total, 317 liver ultrasound images were analyzed, which were provided by the Institute of Nuclear Medicine and Radiation Diagnostics of NAMS of Ukraine. The images were taken by three different sensors (convex, linear, and linear sensor in increased signal level mode). Both images of patients with a normal liver condition and patients with specific liver disease (there were diseases such as: autoimmune hepatitis, Wilson's disease, hepatitis B and C, steatosis, and cirrhosis) were present in the database. Texture analysis was used for "Feature Construction", which resulted in more than a hundred different informative features that made up a common stack. Among them, there are such features as: three authors' patented features derived from the grey level co-occurrence matrix; features, obtained with the help of spatial sweep method (working by the principle of group method of data handling), which was applied to ultrasound images; statistical features, calculated on the images, brought to one scale with the help of differential horizontal and vertical matrices, which are proposed by the authors; greyscale pairs ensembles (found using the genetic algorithm), which identify liver pathology on images, transformed with the help of horizontal and vertical differentiations, in the best possible way. The resulting trait stack was used to solve the problem of binary classification ("norma-pathology") of ultrasound liver images. A Machine Learning method, namely "Random Forest", was used for this purpose. Before the classification, in order to obtain objective results, the total samples were divided into training (70\%), testing (20\%), and examining (10\%). The result was the best three Random Forest models separately for each sensor, which gave the following recognition rates: $93.4 \%$ for the convex sensor, $92.9 \%$ for the linear sensor, and $92 \%$ for the reinforced linear sensor.
\end{abstract}

Keywords: liver diseases; ultrasound imaging; texture analysis; classification; Random Forest

For citation: Nastenko Ie. A., Pavlov V. A, Honcharuk M. O., Hrishko D. Y. Forming the Stack of Texture Features for Liver Ultrasound Images Classification. Herald of Advanced Information Technology. 2020;Vol.3 No.4: 240-251. DOI: 10.15276/hait.04.2020.3

\section{INTRODUCTION}

Medicine has always been considered as one of the most important areas of human activity for almost the entire human race. Thanks to information and computer technologies, this area is rapidly modernizing, as is the diagnostic process [1]. Timely diagnosis of human disease is a very important procedure since it helps to prevent the appearance of serious consequences.

In the context of liver disease diagnosis, one of the most accurate methods is biopsy [2], which is one of the invasive diagnosis types. Nevertheless, this method has many harmful drawbacks, among them: a high percentage of complications (including fatal outcomes), pronounced pain during the procedure (20\% of those surveyed), and close to $9 \%$ of those surveyed said they would never agree to a biopsy again. All this makes the task of non-invasive

(C) Nastenko Ie. A., Pavlov V. A, Honcharuk M. O., Hrishko D. Y., 2020 diagnosis approaches even more actual. The most popular non-invasive method is ultrasound, which, thanks to its speed and affordability, has recently become fundament for information diagnosis systems [3-4]. The only disadvantage of this approach is satisfactory (far from perfect) quality of disease diagnosis, which stabilizes or even worsens with the patients' quantity increase. Therefore, to increase the accuracy of liver disease diagnosis, it is necessary to use the full range of modern approaches to medical image analysis. As a result, there is a possibility to obtain a certain analytical tool (for example the medical images classifier for recognizing pathologies), which becomes a key mechanism for the creation of a decision support system, which provides additional services for doctors while diagnosing a patient.

\section{CLINICAL DATA DESCRIPTION}

The authors of this work were tasked with creating a decision support system for liver 
diagnostics for the Institute of Nuclear Medicine and Radiation Diagnostics of NAMS of Ukraine. The Institute provided 317 liver ultrasound images $b$ mode (Fig. 1).

In total, there are ultrasound images of 46 patients with liver in normal condition and 48 patients with certain liver disease (autoimmune hepatitis, Wilson disease, B and C type hepatitis, steatosis, and cirrhosis among them).

The so-called "regions of interest", or more precisely, the regions of liver ultrasound, which doctors consider to be the most characteristic for identifying pathology, have been marked with red rectangles (Fig. 1). It is these regions of interest (ROI) that have been used in this study as separate objects for analysis. A total of 582 ROIs were identified from each ultrasound's sensor (312 ROI of normal liver and 270 liver pathology ROI).

Another characteristic feature of the data used in the study is that the ultrasound images were taken from different sensors, namely convex, linear, and linear in increased signal mode (marked as "reinforced"). The distribution of norma and pathology for each sensor is as follows: convex sensor - 197 (norma):107 (pathology), linear sensor $-80: 74$, reinforced sensor $-35: 89$.

\section{ANALYSIS OF THE LATEST RESEARCH AND PUBLICATIONS}

The ultrasound only visualizes the surface of the liver, and to represent this on a bitmap image, a so-called "texture" is applied graphically to this surface. This texture makes it possible to obtain valuable information from the images using "texture analysis" methods [5]. Any image is an $m \times n$ ( $m-$ number of rows; $n$ - number of columns) pixel matrix. The matrix shows the grayscale values of grey (since the image is black and white), which range from 0 (black color) to 255 (white color). Using matrices of this type, we can obtain texture features that essentially describe the properties of the image. These features are calculated based on the spatial gray-tone relations of the image. Texture attributes are usually used as texture statistics of the first and higher order [6]. First order statistical features are calculated from the $m \times n$ matrix (grayscale matrix). One of the first applications of this kind of features was the classification of coal worker pneumoconiosis [7]. These features are standard in texture analysis and their use can be found in many papers [8-11].

Statistical features of the second and higher orders are obtained from different types of relationship matrices of gray levels of images. An example of such a matrix is the grey-level cooccurrence matrix (GLCM) [12-13]. The effectiveness of the use of this matrix in the works [14-18] led the authors [19-20] to a detailed study of GLCM and its application to OI liver images. Average GLCMs were constructed separately for normal and pathological images, and the result was obtained in the form of 3D histograms, which are shown in Fig. 2 ( $x$ and $y$ axes show grayscale and $z$ axes shows the average frequency of grayscale combination).

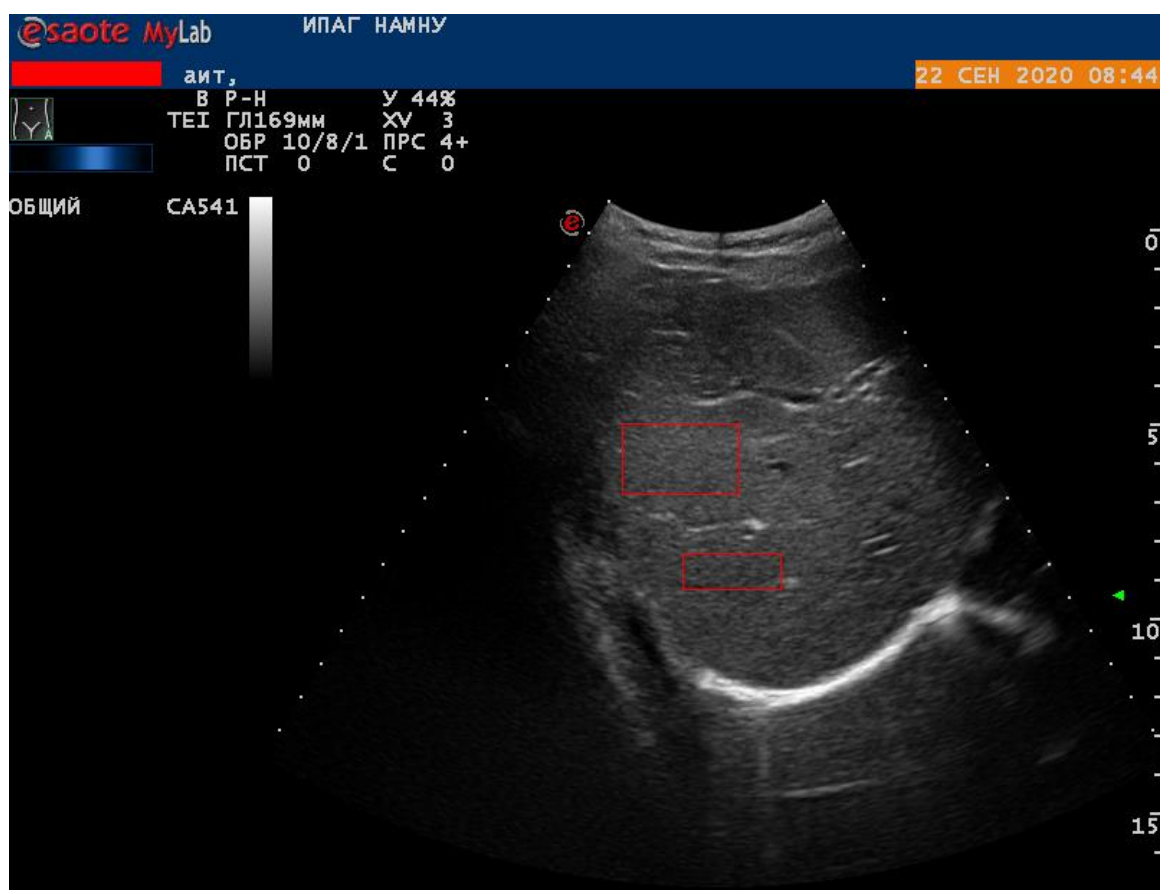

Fig. 1. Example of ultrasound image used in study

Source: Institute of Nuclear Medicine and Radiation Diagnostics of NAMS of Ukraine 


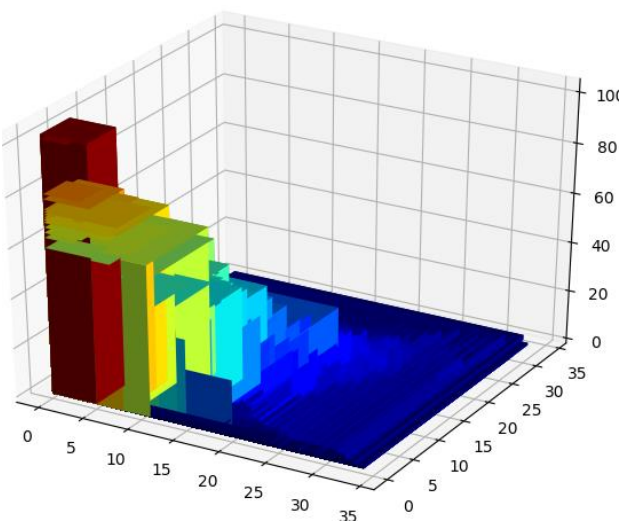

a

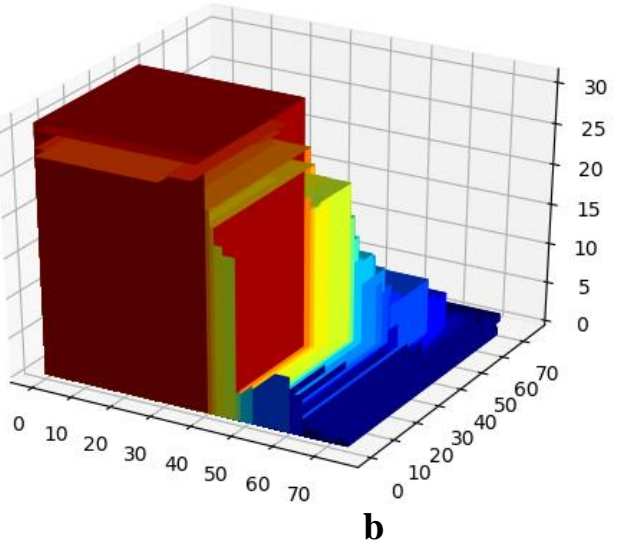

b

Fig. 2. Average GLCMs of:

a-norma; $b$ - pathology

Source: compiled by the author

After comparing obtained histograms, the authors [19-20] were able to get three next features, which are protected by the patent of Ukraine No.139916 on utility model "Diffuse liver disease diagnosis method in children", issued on January 27, 2020:

- $x_{1}$ (Fig. 3) - frequency rate stability range in the area of low-intensity grayscale combinations (the multiplication of a grayscale pair, the combinations of which are most commonly found on GLCM).

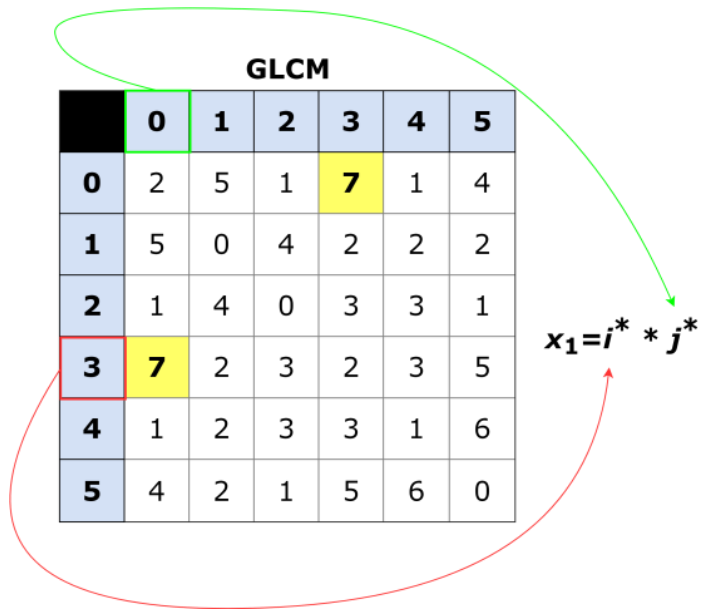

\section{Fig. 3. Definition of feature $x_{1}$}

Source: compiled by the author

- $x_{2}$ (Fig. 4) - frequency of the grayscale pair, which best distinguishes between norm and pathology in liver images.

- $x_{3}$ (Fig. 5) - maximum greyscale value to the level of significance (range of GLCM).

The use of these features enabled the correct recognition of liver pathologies in $93 \%$ of cases [19]. However, at the time, the ROI sample included just over 100 images, and after 500 ROI more were obtained, the result deteriorated markedly. However, the study in [19] found that these features were quite informative, and their combination with other features could provide the necessary analytical tool to recognize liver pathologies with the utmost precision.

\begin{tabular}{|l|l|l|l|l|l|l|}
\hline & $\mathbf{0}$ & $\mathbf{1}$ & $\mathbf{2}$ & $\mathbf{3}$ & $\mathbf{4}$ & $\mathbf{5}$ \\
\hline $\mathbf{0}$ & $\mathbf{2}$ & $\mathbf{5}$ & $\mathbf{1}$ & $\mathbf{7}$ & $\mathbf{1}$ & $\mathbf{4}$ \\
\hline $\mathbf{1}$ & 5 & 0 & 4 & 2 & 2 & 2 \\
\hline $\mathbf{2}$ & 1 & 4 & 0 & 3 & 3 & 1 \\
\hline $\mathbf{3}$ & 7 & 2 & 3 & 2 & 3 & 5 \\
\hline $\mathbf{4}$ & 1 & 2 & 3 & 3 & 1 & 6 \\
\hline $\mathbf{5}$ & 4 & 2 & 1 & 5 & 6 & 0 \\
\hline
\end{tabular}

Fig. 4. Definition of feature $x_{2}$ Source: compiled by the author

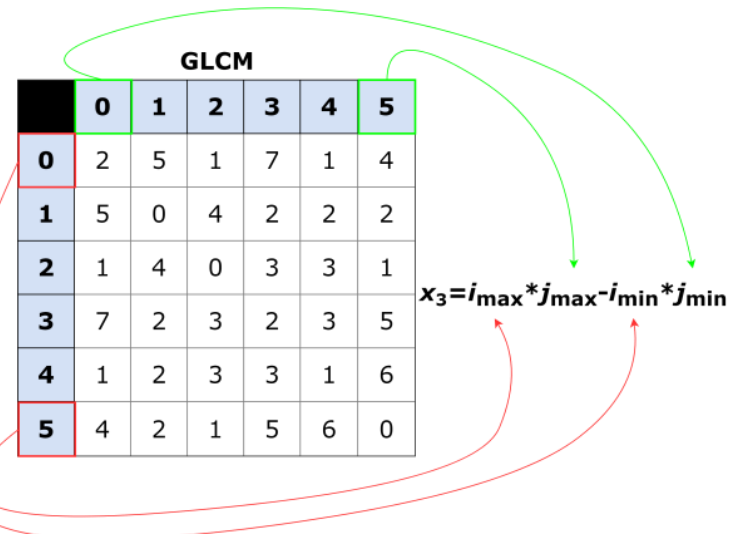

Fig. 5. Definition of feature $\mathbf{x}_{3}$ Source: compiled by the author

\section{RESEARCH OBJECTIVE}

The aim of this work is to use the authors' previous experience (in the form of patented 
textured features) and to obtain new informative features to form a common "stack" of features that describes liver ultrasound images. This stack will be used to improve the accuracy of the liver norma and pathology recognition in ultrasound images by obtaining optimum classification models using Machine Learning methods. Classification models will be obtained separately for convex, linear, and reinforced ROI samples.

The following tasks have been set in accordance with the objective.

1. To obtain new informative texture features.

2. Construction of classification models for three sensors.

\section{Analysis of the results obtained.}

\section{IDENTIFICATION OF NEW TEXTURE FEATURES}

The features proposed by the authors can be divided into the following groups:

- features obtained with the help of linear images sweep;

- features obtained with the help of image differentiation matrices;

- optimal ensembles of grayscale pairs, which best distinguish between norma and liver pathology in the images.

Group 1

Fig. 6 shows examples of liver ROI in normal and pathological conditions.

Comparing these two Figures, we can see that the liver has a more even and grainy texture when it is normal, as opposed to the texture of pathology. This has given rise to the use of the group method of data handling $(\mathrm{GMDH})$ [21-23] to obtain new features. The idea behind the mechanism used is that by analyzing each image, the structure of regression models of multiplicity objects is constructed and observed sequentially over time.

The models take the form of a correlation with the delayed functions in the form:

$$
y_{+P}=F\left(y_{k_{1}}, y_{k_{2}}, \ldots, y_{k_{M}}\right)=\sum_{i=1}^{m} a_{i} \varphi_{i}(y),
$$

where: $P$ - forecast interval; $k_{i}$ - delay index of variable $y$; in which the variable has the greatest correlation with the forecast value $Y$ - vector $\left(y_{k_{1}}, y_{k_{2}}, \ldots, y_{k_{M}}\right)^{T}$.

This made it possible for each type of sensor to build structures that most accurately reflect the classification objects - ROI, in the form of parameter vector $a_{i}(i=1, \ldots, m)$ of model (1).

Thus, the classification of objects occurs in the $a_{i}$ parameter space. The independent variable for the forecast is a series of pixel numbers in a linear image sweep, the dependent variables are grayscale.

Accordingly, as mentioned earlier, ROI are analyzed in the delay space in linear image sweep (by sweep we mean a sequence of rows in the image matrix, and by delay space we mean $m$ values of the autocorrelation function maximums [24] of the sweep)

Thanks to the resulting linear structures of delayed sweeps for each sensor, it is possible to reconstruct the ROI (Fig. 7).

This makes it possible to obtain new informative features in the form of a vector of parameters $a_{i}$, which will be added to the common "stack" of features to recognize liver pathology.

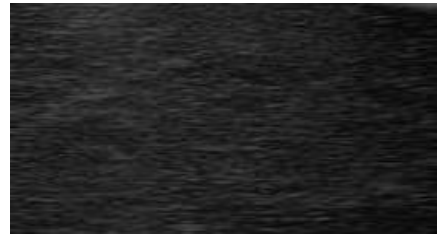

a

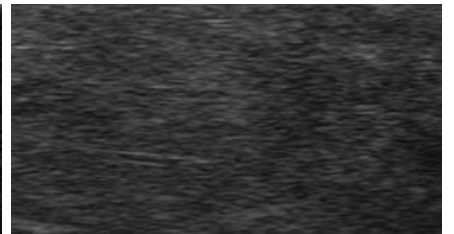

b

Fig. 6. Example of ROI of:

a - liver's norma; b - liver's pathology

Source: compiled by the author

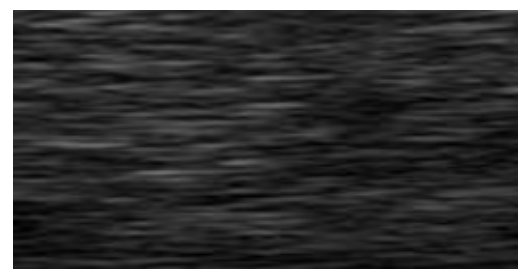

$\mathbf{a}$

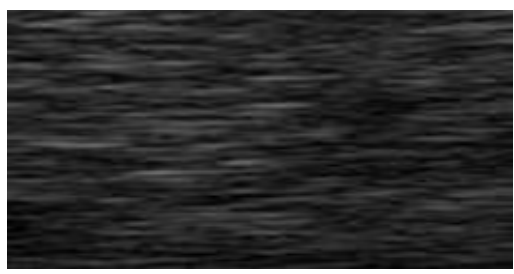

b

Fig. 7. ROI:

$\mathbf{a}$ - original; $\mathbf{b}$ - reconstruction

Source: compiled by the author 


\section{Group 2}

It is worth mentioning that the liver ultrasound images provided by doctors were taken with different brightness and contrast values, which doctors adjusted individually for each patient. Since the authors' patented features $x_{1}, x_{2}$ and $x_{3}$ carry valuable information about the spatial characteristics of ultrasound images, and if standard contrast leveling methods were used, they would be lost, it was decided to develop a mechanism that would not only bring all images into one universal scale but at the same time not lose the spatial characteristics of the images.

This condition made it possible to obtain the following transformation matrices of the original grayscale sensor.

1. Horizontal differentiation matrix (Fig. 8).

The following formula is used to obtain it:

$$
\begin{aligned}
& g_{i, j}^{\text {hor }}=g^{\text {orig }}{ }_{i, j}-g^{\text {orig }}{ }_{i-1, j} \Rightarrow \\
& \Rightarrow g_{i, j}^{* h o r}=g_{i, j}^{\text {hor }}+\left|g_{\text {min }}^{\text {hor }}\right|,
\end{aligned}
$$

where: $g$ - greyscale value; $i$ - row index; $j-$ column index; $\left|g_{\min }^{\text {hor }}\right|-$ module from the minimum horizontal differentiation matrix value.
This transformation provides the image shown in Fig. 9.

2. Vertical differentiation matrix (Fig. 10).

In turn, the following formula is used to obtain it:

$$
\begin{aligned}
& g_{i, j}^{\text {vert }}=g_{i, j}^{\text {orig }}-g_{i, j-1}^{\text {orig }} \Rightarrow \\
& \Rightarrow g_{i, j}^{*_{\text {vert }}}=g_{i, j}^{\text {vert }}+\left|g_{\text {min }}^{\text {vert }}\right|,
\end{aligned}
$$

where: $g$ - greyscale value; $i$ - row index; $j$ column index; $\left|g_{\min }^{\text {vert }}\right|-$ module from the minimum vertical differentiation matrix value.

This transformation provides the image shown in Fig. 11.

Looking more attentively at obtained differentiation results (Fig. 9; Fig.11), it is possible to see that the texture forms remain in the same condition during transformation. This makes it possible to use them for obtaining new texture features without valuable information loss and bringing all images to one universal scale. First of all, $x_{1}, x_{2}, x_{3}$ patent features can be calculated for them.

It was suggested to add first-order texture

\begin{tabular}{|c|c|c|c|c|c|c|}
\hline \multicolumn{7}{|c|}{ Initial greyscale matrix } \\
\hline 53 & 55 & 56 & 61 & 67 & 67 & 65 \\
\hline 52 & 52 & 52 & 57 & 62 & 62 & 58 \\
\hline 60 & 60 & 59 & 60 & 61 & 58 & 54 \\
\hline 66 & 70 & 70 & 69 & 66 & 60 & 54 \\
\hline 68 & 74 & 74 & 72 & 66 & 61 & 58 \\
\hline 68 & 72 & 72 & 69 & 67 & 67 & 67 \\
\hline 68 & 68 & 68 & 68 & 70 & 75 & 74 \\
\hline 67 & 68 & 68 & 69 & 71 & 74 & 75 \\
\hline 65 & 68 & 71 & 73 & 73 & 73 & 73 \\
\hline 66 & 72 & 76 & 76 & 74 & 73 & 74 \\
\hline
\end{tabular}
features to the common stack, which were the following statistical characteristics [25] (calculated on differentiation matrices):

Matrix after differentiation
\begin{tabular}{|c|c|c|c|c|c|}
\hline 2 & 1 & 5 & 6 & 0 & -2 \\
\hline 0 & 0 & 5 & 5 & 0 & -4 \\
\hline 0 & -1 & 1 & 1 & -3 & -4 \\
\hline 4 & 0 & -1 & -3 & -6 & -6 \\
\hline 6 & 0 & -2 & -6 & -5 & -3 \\
\hline 4 & 0 & -3 & -2 & 0 & 0 \\
\hline 0 & 0 & 0 & 2 & 5 & -1 \\
\hline 1 & 0 & 1 & 2 & 3 & 1 \\
\hline 3 & 3 & 2 & 0 & 0 & 0 \\
\hline 6 & 4 & 0 & -2 & -1 & 1 \\
\hline
\end{tabular}

Difference matrix

\begin{tabular}{|c|c|c|c|c|c|}
\hline without negative values \\
\hline 8 & 7 & 11 & 12 & 6 & 4 \\
\hline 6 & 6 & 11 & 11 & 6 & 2 \\
\hline 6 & 5 & 7 & 7 & 3 & 2 \\
\hline 10 & 6 & 5 & 3 & 0 & 0 \\
\hline 12 & 6 & 4 & 0 & 1 & 3 \\
\hline 10 & 6 & 3 & 4 & 6 & 6 \\
\hline 6 & 6 & 6 & 8 & 11 & 5 \\
\hline 7 & 6 & 7 & 8 & 9 & 7 \\
\hline 9 & 9 & 8 & 6 & 6 & 6 \\
\hline 12 & 10 & 6 & 4 & 5 & 7 \\
\hline
\end{tabular}

Fig. 8. Horizontal differentiation

Source: compiled by the author

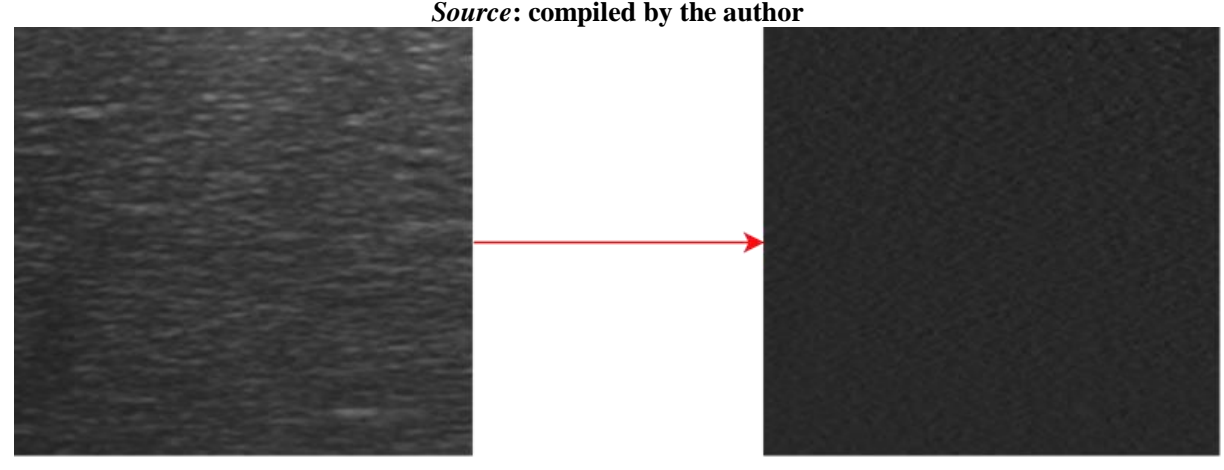

Fig. 9. Result of horizontal differentiation

Source: compiled by the author 


\begin{tabular}{|c|c|c|c|c|c|c|c|c|c|c|c|c|c|c|c|c|c|c|c|c|}
\hline \multicolumn{7}{|c|}{ Initial greyscale matrix } & \multicolumn{7}{|c|}{ Matrix after differentiation } & \multicolumn{7}{|c|}{$\begin{array}{l}\text { Difference matrix } \\
\text { without negative values }\end{array}$} \\
\hline 53 & 55 & 56 & 61 & 67 & 67 & 65 & & & & & & & & & & & & & & \\
\hline 52 & 52 & 52 & 57 & 62 & 62 & 58 & -1 & -3 & -4 & -4 & -5 & -5 & -7 & 6 & 4 & 3 & 3 & 2 & 2 & 0 \\
\hline 60 & 60 & 59 & 60 & 61 & 58 & 54 & 8 & 8 & 7 & 3 & -1 & -4 & -4 & 15 & 15 & 14 & 10 & 6 & 3 & 3 \\
\hline 66 & 70 & 70 & 69 & 66 & 60 & 54 & 6 & 10 & 11 & 9 & 5 & 2 & 0 & 13 & 17 & 18 & 16 & 12 & 9 & 7 \\
\hline 68 & 74 & 74 & 72 & 66 & 61 & 58 & 2 & 4 & 4 & 3 & 0 & 1 & 4 & 9 & 11 & 11 & 10 & 7 & 8 & 11 \\
\hline 68 & 72 & 72 & 69 & 67 & 67 & 67 & 0 & -2 & -2 & -3 & 1 & 6 & 9 & 7 & 5 & 5 & 4 & 8 & 13 & 16 \\
\hline 68 & 68 & 68 & 68 & 70 & 75 & 74 & 0 & -4 & -4 & -1 & 3 & 8 & 7 & 7 & 3 & 3 & 6 & 10 & 15 & 14 \\
\hline 67 & 68 & 68 & 69 & 71 & 74 & 75 & -1 & 0 & 0 & 1 & 1 & -1 & 1 & 6 & 7 & 7 & 8 & 8 & 6 & 8 \\
\hline 65 & 68 & 71 & 73 & 73 & 73 & 73 & -2 & 0 & 3 & 4 & 2 & -1 & -2 & 5 & 7 & 10 & 11 & 9 & 6 & 5 \\
\hline 66 & 72 & 76 & 76 & 74 & 73 & 74 & 1 & 4 & 5 & 3 & 1 & 0 & 1 & 8 & 11 & 12 & 10 & 8 & 7 & 8 \\
\hline
\end{tabular}

Fig. 10. Vertical differentiation

Source: compiled by the author

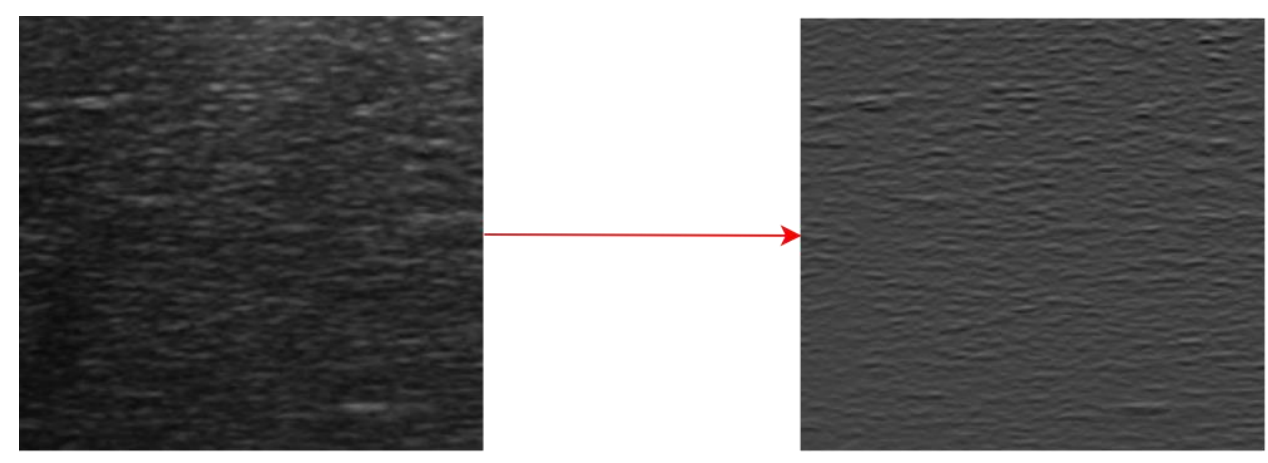

Fig. 11. Result of vertical differentiation

Source: compiled by the author

- mean greyscale value;

- standard deviation;

- skewness;

- kurtosis;

- range;

- median;

- first quartile;

- third quartile;

- interquartile range (the difference between third and first quartile).

Apart from GLCM, so called grey level run length matrix (GLRLM) was studied [26]. The statistical features, mentioned above, were also calculated for this matrix separately for lengths 1,2 , and 3. In addition, the following feature was suggested:

$$
\operatorname{diff}_{i j}=\left|A M o_{i}-A M o_{j}\right|,
$$

where: $\operatorname{diff}_{i j}$ - mode amplitude difference $A M o_{i}$ of GLRLM normalized frequencies at length $i ; i, j=1$, 2,3 .

Feature examples, obtained via formula (4), are shown in Fig. 12 (diff $i j$ marked with red arrows).

\section{Group 3}

The latest innovation of the authors was the features, which are shown as greyscale pair frequencies in GLCM. In order to understand, which greyscale pairs are the most informative for identification of liver pathology, it was necessary to look over $256^{2}$ different features (since there are 256 grey gradations and, consecutively, there are $256 * 256$ gradation pair combinations). On this basis, for initial non-informative feature exclusion for each ultrasound sensor, differential (between liver norm and pathology) GLCMs were calculated on different differentiation matrices. Differential GLCM is the difference between an average norm GLCM and average pathology GLCM. By creating these differential GLCMs, greyscale pairs were excluded by the following principle:

$$
(i, j)=\left\{\begin{array}{cc}
(i, j), & \text { if } d_{i j}<0.3 d_{\text {min }} \\
(i, j), & \text { if } d_{i j}>0.3 d_{\text {max }} \\
\varnothing, & \text { otherwise }
\end{array}\right.
$$




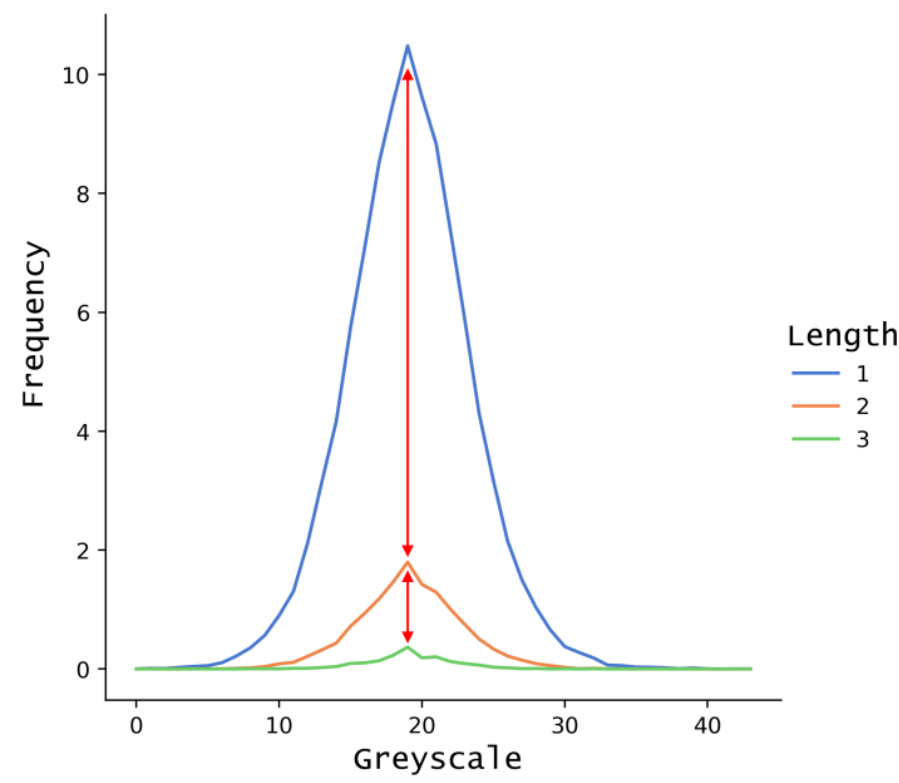

Fig. 12. Visual representation of features diff $_{i j}$ Source: compiled by the author

Nevertheless, there were still a lot of greyscale pairs and therefore the following criterion $S$ [27] was suggested for obtaining an optimal greyscale pair ensemble acting as features:

$$
S=\max \left(\frac{k \overline{r_{c f}}}{\sqrt{k+k(k-1) \overline{r_{f f}}}}\right),
$$

where: $\overline{r_{c f}}-$ the average value of correlation modules of all grayscale pairs with a dependent variable (liver class - norma or pathology); $\overline{r_{f f}}-$ the average value of correlation modules of all grayscale pairs among themselves; $k$ - number of grayscale pairs in the ensemble.

Since the greyscale pairs (the features) contain the quantitative characteristic of frequency, the Spearman's correlation was used [28]. With the help of genetic algorithm [29] the reviewing of different ensembles with given $k$ from 2 to 50 was performed. As a result, the optimal greyscale ensembles were obtained according to the criterion (6), which are shown in Table 1.

The values for the last column were obtained as follows: for each grayscale pair, thresholds were found in the ensemble, which are best divided into norma and pathology, and then the recognition accuracy was calculated.

Thus, the features were obtained, which characterize the rate of greyscale pair occurrence on images, which distinguish norma and pathology best. These features were included in the common stack. It is worth admitting, that the optimum pair ensembles may change with the appearance of new images.

Table 1. Optimal ensembles of greyscale pairs

\begin{tabular}{|c|c|c|c|}
\hline Sensor & $\begin{array}{l}\text { Differentiation } \\
\text { matrix }\end{array}$ & Ensemble of greyscale pairs & $\begin{array}{l}\text { Average } \\
\text { recognition } \\
\text { accuracy }\end{array}$ \\
\hline \multirow[t]{2}{*}{ Convex } & Horizontal & $\begin{array}{c}{[(14,14) ;(19,19) ;(20,13) ;(22,15) ;(30,24) ;} \\
(31,29) ;(32,21) ;(33,33) ;(34,29) ;(37,34) ;(38, \\
34)]\end{array}$ & $63.2 \%$ \\
\hline & Vertical & {$[(40,38) ;(62,55) ;(69,69)]$} & $67.8 \%$ \\
\hline \multirow{2}{*}{ Linear } & Horizontal & $\begin{array}{c}{[(21,17) ;(21,18) ;(26,15) ;(27,15) ;(27,19) ;} \\
(31,19) ;(34,24) ;(35,26)]\end{array}$ & $71.4 \%$ \\
\hline & Vertical & $\begin{array}{c}{[(24,21) ;(36,31) ;(39,34) ;(57,55) ;(63,58) ;} \\
(66,64)]\end{array}$ & $63 \%$ \\
\hline \multirow{2}{*}{ Reinforced } & Horizontal & {$[(19,17) ;(27,27) ;(28,28)]$} & $60.5 \%$ \\
\hline & Vertical & {$[(25,24) ;(46,41)]$} & $52.4 \%$ \\
\hline
\end{tabular}


In this way, features have been obtained which characterize the frequency with which grayscale pairs appear in the image which best distinguishes between norma and pathology. These features have been added to the common stack. It is worth noting that with the advent of new images, the optimal ensembles of pairs may change.

\section{CLASSIFICATION TASK USING THE OBTAINED FEATURES}

All of the proposed features, together with the patented features, made up a common stack (127 features for the convex sensor, 125 features for the linear sensor, and 113 features for the reinforced sensor), which was used to solve the problem of classification, namely, to determine the liver class according to ROI ( 1 - norma, 2 - pathology). One of the most popular Machine Learning methods, the Random Forest [30], has been taken as the classification algorithm, which has recently been considered the best way to solve such problems. Before building the Random Forest, the general samples were broken down into training $(70 \%)$, testing (20\%), and examining (10\%) samples. Each model was assessed for its accuracy of prediction, positive (proportion of correctly predicted first class objects) and negative (proportion of correctly predicted second class objects) predictive values. The results are presented in Table 2 .

If using obtained random forests on general samples $(100 \%)$, the following was obtained: 92.8 $\%$ correct forecasts for convex sensor, $92.9 \%$ for linear one, and $92 \%$ for reinforced one.

There was also an attempt to create random forests for separate feature groups, namely:

- only patent features $x_{1}, x_{2}, x_{3}$;

- only features, calculated on horizontal differentiation matrices;

- only features, calculated on vertical differentiation matrices;

- only model dimension features of spatial sweep;

- only greyscale pair ensembles.

The results of all obtained models are shown in Table 3 .

The feature group results were marked in green, where the random forests for sensors show the maximum forecast accuracy on the general sample. As a result, the features, calculated on horizontal differentiation matrices, have $93.4 \%$ correct forecasts of convex sensor ROI (which is even better, than taking all feature stack), while patent features have $92.2 \%$ correct forecasts of linear sensor ROI and $91.9 \%$ - of reinforced sensor ROI.

\section{CONCLUSIONS AND FURTHER RESEARCH PERSPECTIVE}

As a result of the work performed, the tasks set were completed:

- New groups of features have been identified, which seemed to be the most informative in recognizing liver pathologies in ultrasound images. The textures of liver ultrasound images were analyzed to obtain them. The trick of these feature groups is their almost complete difference in methodology, thus, forming a common feature stack for classification, it is possible to obtain complete texture information.

- Using a classification algorithm called Random Forest, models were built to predict the liver class for each of the three sensor samples, namely a convex sensor (197 normal objects and 107 pathological objects), a linear sensor ( 80 normal objects and 74 pathological objects) and a reinforced sensor (35 normal objects and 89 pathological objects). The common stack of features produced the following results: for the convex sensor $92.8 \%$ correct predictions $(97 \%$ correct predictions of normal objects and $85 \%$ correct predictions of pathological objects), for the linear sensor $92.8 \%$ correct predictions $(99 \%$ correct predictions of normal objects and $86 \%$ correct predictions of pathological objects), for the reinforced sensor $92 \%$ correct predictions $(74 \%$ correct predictions of normal objects and $99 \%$ correct predictions of pathological objects) The features were also divided into groups, and Random Forest was built separately for each group, resulting in one of the groups giving even better results on the convex sensor than the common stack (features calculated on horizontal differentiation matrices were able to correctlyredict $93.4 \%$ of objects, of which $98 \%$ were correctly predicted normal objects and $85 \%$ were correctly predicted pathological objects).

\section{Table 2. Evaluation of resulted Random Forests}

\begin{tabular}{|c|c|c|c|c|c|c|c|c|c|}
\hline \multirow{2}{*}{ Sensor } & \multicolumn{3}{|c|}{ Training sample (70 \%) } & \multicolumn{3}{c|}{ Testing sample (20 \%) } & \multicolumn{3}{c|}{ Examining sample (10 \%) } \\
\cline { 2 - 11 } & Accuracy & PPV & NPV & Accuracy & PPV & NPV & Accuracy & PPV & NPV \\
\hline Convex & $100 \%$ & 1 & 1 & $73.8 \%$ & 0.9 & 0.429 & $80.6 \%$ & 0.9 & 0.636 \\
\hline Linear & $99.1 \%$ & 1 & 0.98 & $80.6 \%$ & 1 & 0.6 & $75 \%$ & 0.875 & 0.625 \\
\hline Reinforced & $100 \%$ & 1 & 1 & $76 \%$ & 0.286 & 0.944 & $69.2 \%$ & 0 & 1 \\
\hline
\end{tabular}


Table 3. Evaluation of resulted Random Forests

\begin{tabular}{|c|c|c|c|c|c|c|c|c|c|}
\hline \multirow{2}{*}{ Sensor } & Training sample (70 \%) & Testing sample (20 \%) & \multicolumn{2}{c|}{ Examining sample (10 \%) } \\
\cline { 2 - 10 } & Accuracy & PPV & NPV & Accuracy & PPV & NPV & Accuracy & PPV & NPV \\
\hline \multicolumn{8}{|c|}{ Patented features $\left(x_{1}, x_{2}, x_{3}\right)$} \\
\hline Convex & $100 \%$ & 1 & 1 & $72.1 \%$ & 0.85 & 0.476 & $80.6 \%$ & 0.9 & 0.636 \\
\hline Linear & $97.2 \%$ & 0.982 & 0.961 & $87.1 \%$ & 0.875 & 0.867 & $68.8 \%$ & 0.75 & 0.625 \\
\hline Reinforced & $100 \%$ & 1 & 1 & $76 \%$ & 0.429 & 0.889 & $69.2 \%$ & 0.25 & 0.889 \\
\hline \multicolumn{8}{|c|}{ Features of horizontally differentiated images } \\
\hline Convex & $100 \%$ & 1 & 1 & $73.8 \%$ & 0.95 & 0.333 & $87.1 \%$ & 0.9 & 0.818 \\
\hline Linear & $96.3 \%$ & 0.964 & 0.961 & $74.2 \%$ & 0.75 & 0.73 & $68.8 \%$ & 0.75 & 0.625 \\
\hline Reinforced & $98.8 \%$ & 0.958 & 1 & $84 \%$ & 0.571 & 0.944 & $46.2 \%$ & 0.25 & 0.556 \\
\hline \multicolumn{8}{|c|}{ Features of vertically differentiated images } \\
\hline Convex & $100 \%$ & 1 & 1 & $68.9 \%$ & 0.85 & 0.381 & $74.2 \%$ & 0.8 & 0.636 \\
\hline Linear & $100 \%$ & 1 & 1 & $74.2 \%$ & 0.938 & 0.533 & $68.8 \%$ & 0.75 & 0.625 \\
\hline Reinforced & $96.5 \%$ & 0.958 & 0.968 & $76 \%$ & 0.429 & 0.889 & $61.5 \%$ & 0.25 & 0.778 \\
\hline \multicolumn{8}{|c|}{ Spatial sweep features } \\
\hline Convex & $100 \%$ & 1 & 1 & $70.5 \%$ & 0.9 & 0.333 & $67.7 \%$ & 0.85 & 0.364 \\
\hline Linear & $100 \%$ & 1 & 1 & $58.1 \%$ & 0.688 & 0.467 & $43.8 \%$ & 0.625 & 0.25 \\
\hline Reinforced & $100 \%$ & 1 & 1 & $76 \%$ & 0.571 & 0.833 & $61.5 \%$ & 0 & 0.889 \\
\hline \multicolumn{8}{|c|}{ Ensembles of greyscale pairs } \\
\hline Convex & $100 \%$ & 1 & 1 & $72.1 \%$ & 0.85 & 0.476 & $61.3 \%$ & 0.75 & 0.364 \\
\hline Linear & $100 \%$ & 1 & 1 & $67.7 \%$ & 0.813 & 0.533 & $62.5 \%$ & 0.625 & 0.625 \\
\hline Reinforced & $95.3 \%$ & 0.917 & 0.968 & $60 \%$ & 0.143 & 0.778 & $84.6 \%$ & 0.5 & 1 \\
\hline
\end{tabular}

Based on the results obtained from Random Forest, the problem of unbalanced classification is visible, i.e. when there are considerably more objects in one class than objects in the second. This has an impact on the perception of the results, in the sense that although the percentage of correct prediction of objects in the overall sample is quite good, there is a high probability of making a first class error because of the small number of objects in one class, i.e. when a sick person is told that he or she is healthy. For a reinforced sensor, this probability is much lower because there are more objects of pathology than normal, but for convex and linear sensors, this problem exists.

Future studies should therefore focus primarily on eliminating the problem of unbalanced classification in order to best achieve the main goal of building a convenient and multifunctional liver diagnostic decision support system that doctors can use in their work without any difficulty.

\section{REFERENCES}

1. Croft, P., Altman, D. G., Deeks, J. J., Dunn, K. M., Hay, A. D., Hemingway, H., et al. "The science of clinical practice: Disease diagnosis or patient prognosis? Evidence about "what is likely to happen" should shape clinical practice". BMC Med. 2015; 13(1): 8 p. DOI: 10.1186/s12916-014-0265-4.

2. Boyd, A., Cain, O., Chauhan, A. \& Webb, G. J. "Medical liver biopsy: indications, procedure and histopathology". Frontline Gastroenterol. 2020; 11(1): 40-47. DOI: 10.1136/flgastro-2018-101139.

3. Dumont, L., Larochelle-Brunet, F., Théoret, H., Riedl, R., Sénécal, S. \& Léger, P. M. "Non-invasive brain stimulation in information systems research: A proof-of-concept study". PLoS One. 2018; 13(7): 16 p. DOI: 10.1371/journal.pone.0201128.

4. Mohammed, M. A., Al-Khateeb, B., Rashid, A. N., Ibrahim, D. A., Abd Ghani, M. K. \& Mostafa, S. A. "Neural network and multi-fractal dimension features for breast cancer classification from ultrasound images". Comput Electr Eng. 2018; 70 p. DOI: 10.1016/j.compeleceng.2018.01.033.

5. Mitrea, D., Nedevschi, S., Cenan, C., Lupsor, M. \& Badea, R. "Exploring texture-based parameters, noninvasive characterization and modeling of diffuse liver diseases and liver cancer from ultrasound images". WSEAS Trans Comput. 2007; 6(2): 283-290.

6. Gao, S., Peng, Y., Guo, H., Liu, W., Gao, T., Xu, Y., et al. "Texture analysis and classification of ultrasound liver images". In: Bio-Medical Materials and Engineering. 2014. p.1209-1216. DOI: 10.3233/BME-130922. 
7. Ledley, R. S., Huang, H. K. \& Rotolo, L. S. "A texture analysis method in classification of coal workers' pneumoconiosis". Comput Biol Med. 1975; 5(1): 53-67. DOI: 10.1016/0010-4825(75)90018-9.

8. Thomas, R., Qin, L., Alessandrino, F., Sahu, S. P., Guerra, P. J., Krajewski, K. M., et al. "A review of the principles of texture analysis and its role in imaging of genitourinary neoplasms". Abdominal Radiology. 2019; Vol.44: 2501-2510. DOI: 10.1007/s00261-018-1832-5.

9. Lubner, M. G., Smith, A. D., Sandrasegaran, K., Sahani, D. V. \& Pickhardt, P. J. "CT texture analysis: Definitions, applications, biologic correlates, and challenges". Radiographics. 2017; Vol.37: 14831503. DOI: $10.1148 / \mathrm{rg} .2017170056$.

10. Lubner, M. G., Stabo, N., Abel, E. J., Munoz Del Rio, A. \& Pickhardt, P. J. "CT textural analysis of large primary renal cell carcinomas: Pretreatment tumor heterogeneity correlates with histologic findings and clinical outcomes". Am J Roentgenol. 2016; 207(1): 96-105. DOI: 10.2214/AJR.15.15451.

11. Haider, M. A., Vosough, A., Khalvati, F., Kiss, A., Ganeshan, B. \& Bjarnason, G. A. "CT texture analysis: A potential tool for prediction of survival in patients with metastatic clear cell carcinoma treated with sunitinib". Cancer Imaging. 2017; 17(1): 9 p. DOI: 10.1186/s40644-017-0106-8

12. Sawyer, T. W., Chandra, S., Rice, P. F. S., Koevary, J. W. \& Barton, J. K. “Three-dimensional texture analysis of optical coherence tomography images of ovarian tissue". Phys Med Biol. 2018; 63(23): 29 p. DOI: 10.1088/1361-6560/aaefd2.

13. Nastenko, Ie. \& Yankovyi, I. "Klasifikator stanu pechinki u ditey z patologiyeyu gepatobiliarnoyi sistemi za teksturnimi statistikami ultrazvukovogo doslidjennia". Biomedichna injeneriya i technologiya. 2019; 2: 15-23 (in Ukrainian).

14. Alazawi, S. A., Shati, N. M. \& Abbas, A. H. "Texture features extraction based on GLCM for face retrieval system". Period Eng Nat Sci. 2019; 7(3): 1459-1467. DOI: 10.21533/pen.v7i3.787.

15. Sharma, E. K., Priyanka, E., Kalsh, E. A. \& Saini, E. K. "GLCM and its Features". Int J Adv Res Electron Commun Eng. 2015; 4(8): 2180-2182.

16. Xu, S. S. D., Chang, C. C., Su, C. T. \& Phu, P. Q. "Classification of liver diseases based on ultrasound image texture features". Appl Sci. 2019; 9(2): 25 p. DOI: 10.3390/app9020342.

17. Raghesh Krishnan, K. \& Radhakrishnan, S. "Focal and diffused liver disease classification from ultrasound images based on isocontour segmentation". IET Image Process. 2015; 9(4): 261-270. DOI: 10.1049/iet-ipr.2014.0202.

18. Yameng, C., Gengxin, S., Yiming, L. \& Jinpeng, Z. "An effective method for cirrhosis recognition based on multi-feature fusion". 2018. 227 p. DOI: 10.1117/12.2304733.

19. Kruglyi, V. \& Nastenko, Ie. "Formirovanie informativnih priznakov dlia zadachi klassifikaciyi patologiya/norma po izobrajeniyu UZI pecheni pacienta". Scientific Discussion. 2019;1(31):57-59 (in Russian).

20. Nastenko, Ie., Dykan, I., Tarasiuk, B., Pavlov, V., Nosovets, O., Babenko, V., Kruglyi, V., Dyba, M. \& Soloduschenko, V. "Klassifikaciya staniv pechinki pri difuznih zahvoruvanniah na osnovi statistichnih pokaznikiv teksturi ultrazvukovih zobrazhen' ta MGUA". Induktivne modelliuvannia skladnih sistem. 2019; 11: 54-66 (in Ukrainian).

21. Teng, G., Xiao, J., He, Y., Zheng, T. \& He, C. "Use of group method of data handling for transport energy demand modeling”. Energy Sci Eng. 2017; 5(5): 302-317. DOI: 10.1002/ese3.176.

22. Nastenko, Ie., Konoval, O., Nosovets, O. \& Pavlov, V. "Set Classification". In: Techno-Social Systems for Modern Economical and Governmental Infrastructures. 2018. p.44-83. DOI: 10.4018/978-15225-5586-5.ch003.

23. Hrishko, D., Trofimenko, O. \& Pavlov, V. "Strukturniy sintez za kriteriyem tochnosti v zadachi klasifikaciyi obyektiv mnojin". Scientific Discussion. 2019; 1(31): 50-52 (in Ukrainian).

24. Nystrup, P., Lindström, E., Pinson, P. \& Madsen, H. "Temporal hierarchies with autocorrelation for load forecasting". Eur J Oper Res. 2020; 280(3): 876-88. DOI: 10.1016/j.ejor.2019.07.061.

25. Scalco, E. \& Rizzo, G. "Texture analysis of medical images for radiotherapy applications". British Journal of Radiology. 2017; Vol. 90: 15p. DOI: 10.1259/bjr.20160642.

26. HimaBindu, G., Anuradha, C. \& Chandra Murty, P. S. R. "Assessment of combined shape, color and textural features for video duplication". Trait $d u$ Signal. 2019; 36(2): 193-199. DOI: $10.18280 /$ ts.360210.

27. Hall, M. A. "Correlation-Based Feature Selection for Machine Learning". 1999. 109 p.

28. Astivia, O. L. O. \& Zumbo, B. D. "Population models and simulation methods: The case of the Spearman rank correlation". Br J Math Stat Psychol. 2017; 70(3): 347-367. DOI: 10.1111/bmsp.12085.

29. Ghaheri, A., Shoar, S., Naderan, M. \& Hoseini, S. S. "The Applications of Genetic Algorithms in Medicine". Oman medical journal. 2015; Vol.30 No 6: 406-416. DOI: 10.5001/omj.2015.82. 
30. Belgiu, M. \& Drăguţ, L. "Random forest in remote sensing: A review of applications and future directions", ISPRS Journal of Photogrammetry and Remote Sensing. 2016; Vol.114: 24-31. DOI: 10.1016/j.isprsjprs.2016.01.011.

Conflicts of Interest: the authors declare no conflict of interest

Received $\quad 30.09 .2020$

Received after revision $\quad 05.11 .2020$

Accepted 18.11.2020

\title{
DOI: 10.15276/hait.04.2020.3
}

UDC 004.9 + 616-079.4

\section{ФОРМУВАННЯ СТЕКУ ТЕКСТУРНИХ ОЗНАК ДЛЯ КЛАСИФІКАЦЇ̈ УЛЬТРАЗВУКОВИХ ЗОБРАЖЕНЬ ПЕЧІНКИ}

\author{
Свген Арнольдович Настенко ${ }^{1)}$ \\ ORCID: https://orcid.org/0000-0002-1076-9337, nastenko.e@ gmail.com \\ Володимир Анатолійович Павлов ${ }^{1)}$ \\ ORCID: https://orcid.org/0000-0002-3293-5308, pavlov.vladimir264@gmail.com \\ Максим Олександрович Гончарук ${ }^{1)}$ \\ ORCID: https://orcid.org/0000-0003-1537-4198, maksymhoncharuk42@ gmail.com \\ Дмитро Юрійович Грішко ${ }^{1)}$ \\ ORCID: https://orcid.org/0000-0003-0731-0098, dimagrshk@ gmail.com \\ 1) Національный технічний університет України «Київський політехнічний інститут імені Ігоря Сікорського», вул. Михайла \\ Брайчевського 5а, Київ, Україна
}

\begin{abstract}
АНОТАЦІЯ
В даній статті розглянуто використання методів текстурного аналізу для отримання інформативних ознак, які описують текстуру ультразвукових зображень печінки. Всього для дослідження було проаналізовано 317 знімків ультразвукового дослідження печінки, які були надані Інститутом ядерної медицини та променевої діагностики НАМН України. Знімки були взяті трьома різними датчиками (конвексним, лінійним, і лінійним датчиком в режимі підвищеного рівня сигналу). У базі присутні як знімки пацієнтів 3 печінкою в нормальному стані, так і пацієнтів 3 певною хворобою печінки (були в наявності такі хвороби, як: аутоімунний гепатит, хвороба Вільсона, гепатит В і С, стеатоз і цироз). За допомогою текстурного аналізу було зроблено «конструювання ознак», що в підсумку дало більше ста різних інформативних ознак, які склали загальний стек. Серед них різняться такі ознаки, як: три запатентованих авторами ознаки, отриманих з матриці суміжності відтінків сірого; ознаки, отримані за допомогою методу просторової розгортки (що працює за принципом методу групового урахування аргументів), який був застосований на ультразвукових зображеннях; статистичні ознаки, пораховані на зображеннях, приведених до єдиної шкали за допомогою запропонованих авторами матриць горизонтальної і вертикальної диференціацій; знайдені за допомогою генетичного алгоритму ансамблі пар градацій сірого, які найкращим чином розрізняють патологію печінки на зображеннях, трансформованих за допомогою горизонтальної і вертикальної диференціацій. Отриманий стек ознак був використаний для вирішення завдання бінарної класифікації («норма-патологія») ультразвукових зображень печінки. Для цього був використаний метод машинного навчання, а саме - «випадковий ліс». Перед виконанням класифікації, для отримання об'єктивних результатів загальні вибірки були поділені на: навчальну $(70 \%)$, тестову $(20 \%)$ і екзаменаційну $(10 \%)$. В результаті були отримані три найкращих моделі випадкового лісу окремо під кожен датчик, які дали такі показники розпізнавання: на конвексному датчику точність розпізнавання дорівнювала $93.4 \%$, на лінійному датчику $-92.9 \%$, на лінійному датчику в посиленому режимі $-92 \%$.
\end{abstract}

Ключові слова: захворювання печінки; ультразвукові дослідження; текстурний аналіз; класифікація; випадковий ліс

DOI: 10.15276/hait.04.2020.3

UDC 004.9 + 616-079.4

\section{ФОРМИРОВАНИЕ СТЕКА ТЕКСТУРНЫХ ПРИЗНАКОВ ДЛЯ КЛАССИФИКАЦИИ УЛЬТРАЗВУКОВЫХ ИЗОБРАЖЕНИЙ ПЕЧЕНИ}

\author{
Евгений Арнольдович Настенко ${ }^{1)}$ \\ ORCID: https://orcid.org/0000-0002-1076-9337, nastenko.e@ gmail.com \\ Владимир Анатольевич Павлов ${ }^{1)}$ \\ ORCID: https://orcid.org/0000-0002-3293-5308, pavlov.vladimir264@ gmail.com \\ Максим Александрович Гончарук ${ }^{1)}$ \\ ORCID: https://orcid.org/0000-0003-1537-4198, maksymhoncharuk42@ gmail.com
}


Дмитрий Юрьевич Гришко ${ }^{1)}$

ORCID: https://orcid.org/0000-0003-0731-0098, dimagrshk@gmail.com 1) Национальный технический университет Украины «Киевский политехнический институт имени Игоря Сикорского», ул. Михаила Брайчевского 5а, Киев, Украина

\begin{abstract}
АННОТАЦИЯ
В данной статье рассмотрено использование методов текстурного анализа для получения информативных признаков, которые описывают текстуру ультразвуковых изображений печени. Всего для исследования было проанализировано 317 снимков ультразвукового исследования печени, которые были предоставлены Институтом ядерной медицины и лучевой диагностики НАМН Украины. Снимки были взяты тремя различными датчиками (конвексным, линейным, и линейным датчиком в режиме повышенного уровня сигнала). В базе присутствовали как снимки пациентов с печенью в нормальном состоянии, так и пациентов с определенной болезнью печени (были в наличии такие болезни, как: аутоиммунный гепатит, болезнь Вильсона, гепатит В и С, стеатоз и цирроз). С помощью текстурного анализа было произведено «конструирование признаков», что в итоге дало больше ста различных информативных признаков, которые составили общий стек. Среди них разнятся такие признаки, как: три запатентованных авторами признака, полученных с матрицы смежности оттенков серого; признаки, полученные с помощью метода пространственной развёртки (работающий по принципу метода группового учёта аргументов), который был применен на ультразвуковых изображениях; статистические признаки, посчитанные на изображениях, приведенных к единой шкале с помощью предложенных авторами матриц горизонтальной и вертикальной дифференциаций; найденные с помощью генетического алгоритма ансамбли пар градаций серого, которые наилучшим образом различают патологию печени на изображениях, трансформированных с помощью горизонтальной и вертикальной дифференциаций. Полученный стек признаков был использован для решения задачи бинарной классификации («нормапатология») ультразвуковых изображений печени. Для этого был использован метод машинного обучения, а именно «случайный лес». Перед произведением классификации, для получения объективных результатов общие выборки были поделены на: обучающую (70 \%), тестовую (20\%) и экзаменационную (10 \%). В результате были получены три наилучших модели случайного леса отдельно под каждый датчик, которые дали следующие показатели распознавания: на конвексном датчике точность распознавания равнялась $93.4 \%$, на линейном датчике $-92.9 \%$, на линейном датчике в усиленном режиме $92 \%$.
\end{abstract}

Ключевые слова: заболевания печени; ультразвуковые исследования; текстурный анализ; классификация; случайный лес

\title{
ABOUT THE AUTHORS
}

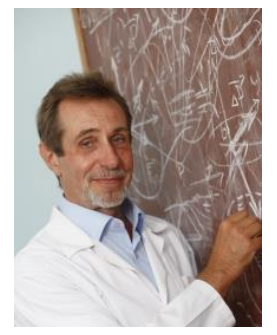

Ievgen Arnoldovich Nastenko - Doctor of Biological Sciences (2008), Candidate of Technical Sciences (1989), Senior Research Officer, Head of Department of the Department of Biomedical Cybernetics. National Technical University of Ukraine "Igor Sikorsky Kyiv Polytechnic Institute". Kyiv. Ukraine

Research field: Life Science; Data Mining; Nonlinear Dynamic Methods; Mathematical Modeling; Biomedical Data Digital Processing; Data Science

Євген Арнольдович Настенко - доктор біологічних наук (2008), кандидат технічних наук (1989), старший науковий співробітник, зав. каф. Біомедичної кібернетики. Національний технічний університет України «Київський політехнічний інститут імені Ігоря Сікорського». Київ. Україна

Евгений Арнольдович Настенко - доктор биологических наук (2008), кандидат технических наук (1989), старший научный сотрудник, зав. кафедрой Биомедицинской кибернетики. Национальный технический университет Украины «Киевский политехнический институт имени Игоря Сикорского». Киев. Украина

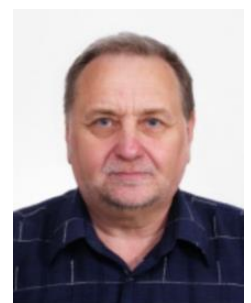

Volodymyr Anatoliyovich Pavlov - Candidate of Technical Sciences (1981), Docent, Associate Professor of the Department of Biomedical Cybernetics. National Technical University of Ukraine "Igor Sikorsky Kyiv Polytechnic Institute". Kyiv. Ukraine Research field: Data Mining; Mathematical Modeling; Biomedical Data Digital Processing; Data Science

Володимир Анатолійович Павлов - кандидат технічних наук (1981), доцент, кафедри Біомедичної кібернетики Національний технічний університет України «Київський політехнічний інститут імені Ігоря Сікорського». Київ. Україна

Владимир Анатольевич Павлов - кандидат технических наук (1981), доцент каф. Биомедицинской кибернетики. Национальный технический университет Украины «Киевский политехнический институт имени Игоря Сикорского». Киев. Украина

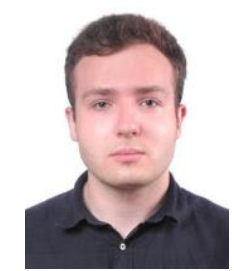

Maksym Oleksandrovych Honcharuk - Department of Biomedical Cybernetics. National Technical University of Ukraine "Igor Sikorsky Kyiv Polytechnic Institute". Kyiv. Ukraine

Research field: Information Technologies in Medicine; Computer Science; Data Science; Deep Learning; Artificial Intelligence

Максим Олександрович Гончарук - кафедра Біомедичної кібернетики. Національний технічний університет України «Київський політехнічний інститут імені Ігоря Сікорського». Київ. Україна

Максим Александрович Гончарук - кафедра Биомедицинской кибернетики. Национальный технический университет Украины «Киевский политехнический институт имени Игоря Сикорского». Киев. Украина

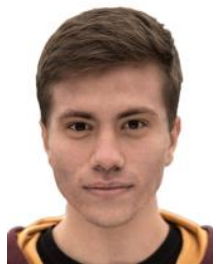

Dmitro Yuriiovych Hrishko - Department of Biomedical Cybernetics National Technical University of Ukraine "Igor Sikorsky Kyiv Polytechnic Institute". Kyiv. Ukraine

Research field: Information Technologies in Medicine; Computer Science; Data Science; Deep Learning; Computer Vision

Дмитро Юрійович Грішко - каф. Біомедичної кібернетики. Національного технічного університету України «Київський політехнічний інститут імені Ігоря Сікорського». Київ. Україна

Дмитрий Юрьевич Гришко - каф. Биомедицинской кибернетики. Национального технического университета Украины «Киевский политехнический институт имени Игоря Сикорского». Киев. Украина 